\title{
Determinants of IPO Underpricing on the Warsaw Stock Exchange
}

\author{
Yuliya Kavalenka*
}

\begin{abstract}
Purpose - the objective of this paper is to provide evidence on the initial return (IR) of Initial Public Offerings (IPO) on the stock market in Poland and to identify determinants of the IPO initial returns on the Warsaw Stock Exchange (WSE) in the period between the years 2005 and 2015.

Design/methodology/approach - empirical analysis and regression results estimation based on information derived from databases such as: Bloomberg, Dealogic, and MergerMarket.

Findings - the paper provides evidence for information asymmetry, behavioural as well as ownership and structure theories. The results identify six variables which have an impact on the degree of underpricing namely, involvement of PE and VC funds in the ownership structure of a company undertaking an IPO, new shares issued as a percentage of an IPO's total proceeds, ex-ante uncertainty measured by Parkinson's extreme value, an IPO price being set at the maximum of the book building range, turnover of shares traded during the debut date as well as the stock market return six months prior to an IPO.

Originality/value - this paper contributes to the literature providing new evidence on a relatively little researched IPO underpricing phenomenon and determinants on the Polish stock market.
\end{abstract}

Keywords: IPO, underpricing, Warsaw Stock Exchange

\section{Introduction}

IPO underpricing is one of the best-documented empirical findings in finance. Numerous studies have been conducted to build an impressive body of evidence worldwide, which firmly establishes the fact that IPOs are generally priced at a substantial discount from the prices, that prevail in the aftermarket. Ritter (2016) provides an extensive paper with international insights of the analysed initial returns in 52 countries, which range from an average of $3.3 \%$ for Russia to $239.8 \%$ for Saudi Arabia. Since 1969, when Reily, Frank and Hatfield introduced the first evidence of IPOs underpricing, considerable effort in both theoretical and empirical fields has been devoted to explain the phenomenon of IPO underpricing.

The majority of the studies attribute information asymmetry as the primary reason for the IPO underpricing. Beatty and Ritter (1986) claimed that the greater the ex-ante uncertainty, the higher the expected underpricing. Rhee (2002) in his review states, that IPO underpricing is used by firms as a mechanism for signalling a firm's quality: issuer identified

\footnotetext{
* mgr Yuliya Kavalenka, PhD candidate at Kozminski University, Jagiellońska 57/59, 03-301 Warsaw, e-mail: julia. kavalenka@gmail.com.
} 
as a "high quality" intentionally underprice IPOs in order to ensure more successful equity offerings in the future (Allen, Faulhaber, 1989; Grinblatt, Hwang, 1989; Welch, 1989, 1992). Other studies focus on specific factors explaining IPO underpricing. Booth and Smith (1986), Titman and Trueman (1986), Balvers, McDonald, and Miller (1988), Carter and Manaster (1990) suggested that advising agents quality (investment banks, accounting and auditing firms) negatively effects IPO underpricing levels. Ritter and Welch (2002) studied IPOs activity in the period of 1980-2001. They identified number of reasons for IPO underpricing under the condition of symmetric information and asymmetric information.

The late 1990s introduced advanced explanations for IPO underpricing which depart from traditional informational asymmetries explanations. In the latest theories IPO underpricing is associated with, among other factors, insiders' preference for wider outside ownership to enhance liquidity or to entrench themselves (Booth, Chua, 1996), insiders' wealth effects (Loughran, Ritter, 2002), the lock-up commitment imposed on insiders (Mohan, Chen, 2001; Brav, Gompers, 2003) and the role of location and proximity in stock markets (Coval, Moskowitz, 2001; Massa, Simonov, 2006; Gurun, Butler, 2012) and superior local information in rural areas - rural areas should experience less IPO underpricing, because superior local information in such areas lowers uncertainty regarding the IPO value (Bodnaruk, 2009).

Regarding Polish market evidence, Aussenegg (2000) performed an analysis for Polish IPOs between 1991 and 1999 for two categories of companies - public and private sectors. The average initial return of $38.5 \%$ demonstrates that these IPOs were substantially underpriced, with public sector IPOs yielding significantly higher average returns than those of the private sector $-65.6 \%$ compared to $25.3 \%$ respectively. Lyn and Zychowicz (2002) studied the performance of 103 IPOs on Hungarian and Polish markets between 1991 and 1998. Their findings show that average market-adjusted initial returns in Poland equalled $15.1 \%$ and $54.4 \%$ in Hungary. The authors show that the key determinant of IRs on those markets was market momentum, measured as the return of the local market index over one month prior to the IPO debut date. Sukacz (2005) analysed 185 IPOs in Poland between 1991 and 2002. The findings show that first-day average underpricing equalled 26\%. Found determinants of IPOs underpricing are (1) percentage change of the WIG - broad Polish market index - between the first trading day and the last day of the subscription period, (2) number of days between the end of the subscription period and the first day trading date, (3) financial ratios $\mathrm{P} / \mathrm{BV}$ and $\mathrm{P} / \mathrm{E}$. The first two variables show positive relations, while the later has a negative effect. Sieradzki (2013) analysed 314 IPOs carried out on the Polish stock market in the years 2003-2011. The average initial return equalled $14.2 \%$. Private domestic companies IPOs and offers of companies, which migrated from other markets, show the highest initial returns. This observation contradicts the information asymmetry theory. These results are supported by Jewartowski and Lizinska (2012). The authors studied the short and long-term performance of IPOs in Poland between the years 2000-2008. Their 
study showed positive initial market-adjusted returns of $13.95 \%$ and long-term underperformance with a mean of $-22.62 \%$ for the three years buy-and-hold strategy.

The purpose of this paper is to determine which factors affect the initial returns of IPOs on the WSE, provided a new set of variables. Comparing to the US and the UK - markets, on which most of the theories have been tested - IPO market in Poland is not covered enough, mainly due to the size of the market as compared to its western peers. This paper adds value to the former studies by examining IPO initial returns on the Polish market in the period between 2005 and 2015 and identifying new determinants of the degree of underpricing.

\section{Data collection and hypotheses development}

During the research period, namely between the years 2005-2015, 372 IPOs were conducted on the WSE, including 49 transfers from NewConnect ${ }^{1}$. The data for the empirical analysis collected originate from the WSE, companies' prospectuses, Bloomberg, Dealogic as well as MergerMarket. After the exclusion of transfers from NewConnect, which did not have new shares issued in the process of transfers, and observations with missing variables the final sample utilised in regression consists of 281 IPOs.

IPO's initial return is calculated as the difference between the first trading day close price and the issue price as follows (this approach is used for instance by Al-Hassan et al., 2007, Sieradzki, 2013):

where:

$$
I R_{i, t}=\frac{P_{i, t}-P_{i, 0}}{P_{i, 0}}
$$

$I R_{t, t}-$ the initial return of a company $i$ at period $t$,

$P_{i, t}$ - closing price of the security $i$ on the first trading day,

$P_{i, 0}-$ issue price of the security $i$.

The literature suggests many theories which attempt to explain the degree of IPO underpricing. These theories may be broadly grouped in four categories: asymmetric information, ownership and control, institutional and behavioural. This paper analyses how certain variables, which correspond to three (except for institutional) of the aforementioned theories, can explain the degree of IPO underpricing on the WSE. The hypotheses development is presented as follows:

\footnotetext{
${ }^{1}$ NewConnect is an organised market that is operated by the WSE outside the regulated market as an alternative trading system. Please see www.newconnect.pl.
} 


\section{Capital offered (CapitalOffered)}

\begin{tabular}{ll}
\hline Hypothesis & $\begin{array}{l}\text { There is a negative relationship between the degree of underpricing and the portion of capital } \\
\text { offered in an IPO }\end{array}$ \\
\hline \multirow{3}{*}{ Justification } & $\begin{array}{l}\text { Practice shows that companies often conduct equity offerings in two or more stages (Welch, } \\
\text { 1989; Michaely, Shaw, 1994). Over the first stage (that is an IPO) - firms offer a relatively } \\
\text { small proportion of shares which are sold at lower prices. The firm's intention of losing issue } \\
\text { proceed in the first place may be to create positive attitude to the firm among investors. Thus, } \\
\text { a negative correlation is expected between the level of underpricing and the proportion of } \\
\text { shares offered }\end{array}$ \\
\hline Metrics & $\begin{array}{l}\text { Capital offered is measured as the ratio of the number of shares offered to the number of firm's } \\
\text { outstanding shares before IPO }\end{array}$ \\
\hline
\end{tabular}

\section{Ex-ante uncertainty (PEV)}

\begin{tabular}{ll}
\hline Hypothesis & There is a positive relationship between the degree of underpricing and the ex-ante uncertainty \\
\hline Justification & $\begin{array}{l}\text { One explanation for underpricing is that issuers expect investors' ex-ante uncertainty related to } \\
\text { the future performance of the firm seeking an IPO. Investors are less informed about a firm's } \\
\text { prospects than its managers, and managers in turn are less informed about the aggregate de- } \\
\text { mand for the equity offering than the market }\end{array}$ \\
\hline & $\begin{array}{l}\text { Following Knopf and Teall (1999) and inspired by Sieradzki (2013), Parkinson's Extreme } \\
\text { Value (PEV) is calculated as follows: }\end{array}$ \\
Metrics & $P E V=\ln _{i, 0} \frac{P_{i, 0} \text { max }}{P_{i, 0} \min }$,
\end{tabular}

\section{Issue price established at the maximum of the book building price range (IssueatMax)}

\begin{tabular}{ll}
\hline Hypothesis & $\begin{array}{l}\text { There is a positive relationship between the degree of underpricing and the issue price which } \\
\text { is set at the maximum level of the price range set by the underwriter }\end{array}$ \\
\hline \multirow{3}{*}{ Justification } & $\begin{array}{l}\text { Issue price which is set at the maximum level may indicate the potential demand for the issue } \\
\text { and used as an alternative to an oversubscription proxy which is used by some empirical } \\
\text { studies (Rock, 1986; Paudyal, 1998) }\end{array}$ \\
\hline Metrics & Dummy variable \\
\hline
\end{tabular}

\section{Industry Classification - Internet \& Software (IntSoft)}

\begin{tabular}{ll}
\hline Hypothesis & There is a positive relationship between the degree of underpricing and High-Tech firms \\
\hline Justification & $\begin{array}{l}\text { High-Tech firms are perceived as being more innovative though riskier, thus increasing the } \\
\text { degree of underpricing }\end{array}$ \\
\hline Metrics & Dummy variable for the internet or software sector firms \\
\hline
\end{tabular}




\section{PE/VC backed IPOs (PEVCbacked)}

\begin{tabular}{ll}
\hline Hypothesis & There is a negative relationship between the degree of underpricing and PE/VC backed IPOs \\
\hline Justification & $\begin{array}{l}\text { The Certification effect hypothesis which states that PE and VC investors with good reputa- } \\
\text { tions are able to value a firm more accurately (Muscarella, Peavy, Vetsuypens, 1990) }\end{array}$ \\
\hline Metrics & Dummy variable for PE/VC backed IPOs \\
\hline
\end{tabular}

\section{Offer Size (OfferSize)}

\begin{tabular}{ll}
\hline Hypothesis & There is a negative relationship between the degree of underpricing and an IPO value \\
Justification & $\begin{array}{l}\text { Offer size may be treated as a proxy for the issue risk level. Larger IPOs are considered less } \\
\text { risky than smaller IPOs and, hence, lead to the lower degree of underpricing }\end{array}$ \\
Metrics & Natural logarithm of IPO value
\end{tabular}

\section{Turnover Ratio (Turnover)}

\begin{tabular}{ll}
\hline Hypothesis & $\begin{array}{l}\text { There is a positive relationship between the degree of underpricing and the ratio of the num- } \\
\text { ber of shares traded on the first day to the total number of shares sold in an IPO }\end{array}$ \\
\hline $\begin{array}{l}\text { High turnover ratio may indicate a speculative demand for shares. One possible explanation } \\
\text { is that investors, who buy shares in an IPO are interested in short-run performance only and } \\
\text { are intended to sell shares during the first listing day. Another explanation is that investors, } \\
\text { especially in the period of a hot market, who did not receive the desired amount of shares due } \\
\text { to higher than expected reduction rates, are buying additional shares during the first listing } \\
\text { day }\end{array}$ \\
$\begin{array}{l}\text { Inspired by Sieradzki (2013), turnover ratio is calculated as follows: } \\
\text { Metrics }\end{array}$ \\
Turnover Ratio $=\frac{\text { number of shares traded during the debut day }}{\text { number of shares sold in an IPO }}$.
\end{tabular}

\section{Market Return (MarketReturn)}

\begin{tabular}{ll}
\hline Hypothesis & $\begin{array}{l}\text { There is a positive relationship between the degree of underpricing and market return over six } \\
\text { months prior to an IPO }\end{array}$ \\
\hline \multirow{3}{*}{ Justification } & $\begin{array}{l}\text { Partially refers to a "hot" market concept. Generally, "hot" period IPOs are associated with } \\
\text { a higher degree of underpricing. "Hot" markets are perceived as a result of market bullishness } \\
\text { and thus a chance for managers to take advantage of a "time window" for their firms' IPO }\end{array}$ \\
\hline Metrics & Return of the WIG index over a six-month period prior to an IPO \\
\hline
\end{tabular}

\section{Market Volatility (MarketVolatility)}

\begin{tabular}{ll}
\hline Hypothesis & $\begin{array}{l}\text { There is a positive relationship between the degree of underpricing and market volatility six } \\
\text { months to an IPO }\end{array}$ \\
\hline & $\begin{array}{l}\text { In times of more volatile markets, underwriters are inclined to underprice more in order to } \\
\text { make a successful issue. Thus, a positive relation between market volatility and the level of } \\
\text { underpricing is expected. Such a relation was described by Menyah et al (1995) for the UK } \\
\text { stock market }\end{array}$ \\
\hline Metrics & Standard deviation of daily returns of the WIG index over a six-month period prior to an IPO \\
\hline
\end{tabular}


New shares issued as a percentage of IPO (NewSharesIssued)

\begin{tabular}{ll}
\hline Hypothesis & $\begin{array}{l}\text { There is a negative relationship between the degree of underpricing and a per cent of the IPO } \\
\text { total proceeds which were destined for the newly issued shares }\end{array}$ \\
\hline \multirow{3}{*}{ Justification } & $\begin{array}{l}\text { I would expect that the shareholders of the company issuing more additional shares in an } \\
\text { IPO, thus giving the market a signal in their confidence in the success of an IPO and consequ- } \\
\text { ently reducing information asymmetry }\end{array}$ \\
\hline Metrics & New shares issued as a percentage of IPO total proceeds \\
\hline
\end{tabular}

\section{Model and results discussion}

Between 2005 and 2015, the average initial return in the final dataset equals $9.2 \%$ and the median is $4.4 \%$. Although on average investments in IPOs have been profitable, he number of IPOs with negative initial returns is quite high ( 77 or $28 \%$ of all equity offerings in the studied period). The descriptive statistics for initial returns and the variables described above, as determinants for underpricing, are summarized in Table 1.

\section{Table 1}

Descriptive statistics for dependent and independent variables

\begin{tabular}{llllllll}
\hline Variable & Mean & Median & Minimum & Maximum & $\begin{array}{l}\text { Standard } \\
\text { Deviation }\end{array}$ & Skewness & Ex. Kurtosis \\
\hline IR & 0.09175 & 0.04385 & -0.74074 & 2.0133 & 0.26753 & 2.4063 & 12.134 \\
PEVCbacked & 0.15714 & 0.000 & 0 & 1 & 0.36459 & 1.8842 & 1.5501 \\
NewSharesIssued & 0.74166 & 1.000 & 0 & 1 & 0.35864 & -1.0482 & -0.42937 \\
CapitalOffered & 28.172 & 25.087 & 0.34 & 100 & 15.862 & 1.298 & 2.9296 \\
PEV & 0.08932 & 0.06043 & 0 & 1.5078 & 0.13104 & 6.8209 & 61.9 \\
Turnover & 0.4462 & 0.01058 & 0 & 110.49 & 6.6007 & 16.636 & 274.84 \\
IssueatMax & 0.31786 & 0 & 0 & 1 & 0.46648 & 0.78233 & -1.388 \\
MarketReturn & 8.355 & 8.5901 & -44.341 & 58.992 & 16.056 & -0.43495 & 0.59528 \\
MarketVolatility & 1.1466 & 1.1485 & 0.65482 & 2.5232 & 0.34798 & 0.92304 & 1.5485 \\
IntSoft & 0.025 & 0 & 0 & 1 & 0.1564 & 6.0849 & 35.026 \\
OfferSize* & 284.71 & 49.221 & 0.135 & 10720 & 1045.2 & 6.8043 & 52.222 \\
\hline
\end{tabular}

"Statistics presented for offer size in real not log values.

Source: own calculations.

The correlation matrix is presented in Table 2 and the figures observed suggest the lack of a multicollinearity problem.

In order to determine which variables explain the underpricing on the WSE between 2005 and 2015 and test if the above-mentioned hypotheses can be rejected or not, an ordinary least squares regression has been performed with IR being the dependent variable. The final regression model controlling for all the factors identified before is as follows: 


$$
\begin{gathered}
\text { IR }=\beta_{1} \times \text { PEVCbacked }+\beta_{2} \times \text { NewSharesIssued }+\beta_{3} \times \text { CapitalOffered }+\beta_{4} \times \text { PEV }+ \\
+\beta_{5} \times \text { Turnover }+\beta_{6} \times \text { IssueatMax }+\beta_{7} \times \text { MarketReturn }+\beta_{8} \times \text { MarketVolatility }+ \\
+\beta_{9} \times \text { IntSoft }+\beta_{10} \times \text { OfferSize }
\end{gathered}
$$

\section{Table 2}

Correlation matrix for dependent and independent variables

\begin{tabular}{ccccl}
\hline IR & PEVCbacked & NewSharesIssued & CapitalOffered & \\
\hline & -0.0549 & -0.0178 & 0.0169 & IR \\
& & -0.3377 & 0.1640 & PEVCbacked \\
PEV & Turnover & IssueatMax & -0.3961 & NewSharesIssued \\
0.0193 & -0.1817 & 0.2602 & 0.2799 & IR \\
0.0325 & -0.0225 & -0.1051 & 0.0105 & PEVCbacked \\
0.0670 & 0.0381 & 0.0821 & -0.0404 & NewSharesIssued \\
-0.1120 & -0.1025 & 0.0306 & 0.2025 & CapitalOffered \\
& 0.6538 & 0.0064 & -0.1350 & PEV \\
& & -0.0406 & -0.1689 & Turnover \\
& & 0.3115 & IssueatMax \\
& MarketVolatility & IntSoft & OfferSize & \\
& 0.0409 & -0.0324 & -0.0025 & IR \\
& -0.0627 & -0.0691 & -0.0052 & PEVCbacked \\
0.2023 & 0.0632 & -0.4640 & NewSharesIssued \\
-0.2113 & 0.0309 & 0.3521 & CapitalOffered \\
0.2373 & -0.0215 & -0.2481 & PEV \\
0.2021 & -0.0102 & -0.2256 & Turnover \\
0.0912 & -0.0111 & -0.0194 & IssueatMax \\
-0.2261 & 0.0302 & 0.2093 & MarketReturn \\
& -0.0551 & -0.1929 & MarketVolatility \\
& & 0.0143 & IntSoft \\
\hline
\end{tabular}

Source: own calculations.

\begin{tabular}{|c|c|c|c|c|c|}
\hline & Coefficient & Std. error & t-ratio & p-value & \\
\hline 1 & 2 & 3 & 4 & 5 & 6 \\
\hline Const & 0.079373 & 0.07382 & 1.0752 & 0.2832 & \\
\hline PEVCbacked & -0.0666915 & 0.0401115 & -1.6627 & 0.0975 & $*$ \\
\hline NewSharesIssued & -0.0955355 & 0.0411824 & -2.3198 & 0.0211 & $* *$ \\
\hline CapitalOffered & -0.000455128 & 0.00105946 & -0.4296 & 0.6678 & \\
\hline PEV & 0.454996 & 0.183518 & 2.4793 & 0.0138 & $* *$ \\
\hline Turnover & -0.0129584 & 0.00256184 & -5.0582 & $<0.0001$ & $* * *$ \\
\hline
\end{tabular}

\section{Table 3}

Ordinary least squares regression results (heteroscedasticity-robust standard errors, variant HC1) 


\begin{tabular}{lclrll}
\hline 1 & 2 & 3 & 4 & 5 & 6 \\
\hline IssueatMax & 0.0915272 & 0.0381681 & 2.3980 & 0.0172 & $* *$ \\
MarketReturn & 0.00415689 & 0.00113043 & 3.6773 & 0.0003 & $* * *$ \\
MarketVolatility & 0.0675965 & 0.0493938 & 1.3685 & 0.1723 & \\
IntSoft & -0.0474168 & 0.0527633 & -0.8987 & 0.3696 & \\
OfferSize & -0.0170883 & 0.0144749 & -1.1805 & 0.2388 & \\
R-squared & 0.185319 & & & & \\
p-value (F) & $4.9 \mathrm{e}-119$ & & & & \\
\hline
\end{tabular}

Source: own calculations.

The regression results show that six variables have a statistically significant effect on initial returns, which confirm the presence of irrational investors on the Polish stock market (proxied by behavioural variables namely, turnover ratio, an issue set at maximum, market return prior to an IPO), importance of information asymmetry impact (proxied by variables with new shares issued as a percentage of IPO's total proceeds and PEV) as well as an ownership structure (proxied by the dummy variable controlling the involvement of PE and $\mathrm{VC}$ funds).

First, the dummy variable indicating the involvement of private equity and venture capital investors confirm the stated hypothesis. $\mathrm{PE} / \mathrm{VC}$ funds involvement does have an impact on the IPO pricing. These results that the company undertaking an IPO, backed by the private equity or venture capital fund, exhibit a lower degree of underpricing confirm one stream in the literature, which argue that $\mathrm{PE} / \mathrm{VC}$ funds reduce asymmetry information between investors and managers of the firm by their superior business monitoring which, in turn, leads to lower underpricing (Barry, Muscarella, Peavy, Vetsuypens, 1990). Meggision and Weiss (1991) claimed that PE/VC investors act as certifying agents to the issuer. Authors' studied PE/VC backed IPOs and compared its performance with non-backed IPOs in the period between 1983 and 1987 in the US. The results show that PE/VC backed IPOs exhibit less underpricing supporting the certification effect: PE and VC investors with good reputations are able to value the firm more accurately. This hypothesis was confirmed by Carter and Manaster (1991). Chachine (2006) also emphasized the importance of the certification role and observed, that PE/VC backed IPOs in the UK are less underpriced than, normal ones. Lin and Smith (1998) showed, that good reputation PE/VC backed IPOs exhibit less underpricing.

A newly proposed variable - shares issued in the IPO process - has also been found to confirm the stated hypotheses and have a negative impact on the degree of underpricing. The intuition behind this variable is that shareholders' intention of issuing more new shares in the process of going public may provide additional evidence on the information asymmetry determinants. Issuing new shares indicates the willingness of the current shareholders to not be diluted after the IPO process, which may indicate and signal in the market their confidence in the company's prospects and success of an IPO process. Also, issuing 
additional issues besides the sale of the existing shares may serve as a signal for the market that shareholders are confident about the positive outcome of an IPO.

Next, ex-ante uncertainty variable - PEV - confirms the stated hypotheses of a positive relationship on the degree of underpricing. These results go along with the conclusions of Sieradzki (2013). Issue price set at the maximum of the set range in the book building process and the overall stock market return in the last six months also confirm the stated hypotheses and have a positive effect on the IR.

A striking result is that the relationship of the turnover ratio and the degree of underpricing is opposite to the one derived from the hypotheses development and to the results obtained by Sieradzki (2013). Such results need further literature evidence in Poland to be compared with and contrasted to. However, it may also indicate that high turnover ratio does not necessarily correspond to speculative demand for shares in an IPO during the first trading day. The structure of the offer is also an insignificant proxy for IPO underpricing. It shows, that investors do not pay attention, to what proportion of a company's shares are being offered. Market volatility does not have a statistically significant impact which may suggest that if the market is volatile, companies tend to postpone their IPO. Next, with regards to information asymmetry, the IPOs of large firms do not reveal more information, than the offers of smaller ones. This finding is consistent with Sieradzki (2013) results for the years 2003-2011, and with the results obtained by Lyn and Zychowicz, that analysed the IPO market in Hungary and in Poland between the years 1991-1998. Industry characteristics (internet and software specialisations) do not seem to have an impact on the degree of underpricing on the WSE, which may be explained by the fact, that investors' preferences do not remain the same for such a long period of time as ten years and tend to change from one period to another.

This research is exposed to certain limitations, which may affect the results and cause problems with an interpretation of the outcomes. The first possible issue is the omitted variables bias. The model constructed could explain only $18.5 \%$ of the variations of IPOs underpricing in the studied period. Referring to the previous studies results (Lyn, Zychowicz, 2003; Sieradzki, 2013), this research suggests, that there are other important variables, i.e. other ex-ante uncertainty proxies, agency conflicts, investor sentiment, ownership and other behavioural explanations, that have been omitted from the model, that could increase the model's explanatory power. Next, a clearer picture on investor sentiments for industries for specific periods between the years 2005-2015 may be performed. Investors' preferences for certain industries tend to change over time, due to the increase in the decrease of its attractiveness under different circumstance in the financial, political, socio environment.

Finally, based on the collected sample data and the results derived from the cross-section models, there are few areas for further research. Further research on the subject may include adding more control factors and proxies for institutional and ownership theories that influence the underpricing of IPOs. 


\section{References}

Al-Hassan, A., Delgado, F., Omran, M. (2007). IPO behabior in GCC countries: Goody-two shoes or Bad-to-theBone? International Monetary Fund.

Allen, F., Faulhaber, G. (1989). Signaling by underpricing in the IPO market. Journal of Financial Economics, 23, 303-324.

Aussenegg, W. (2000). Privatization versis private sector: Initial public offerings in Poland. Multinational Finance Journal, 1-2 (4), 69-99.

Balvers, R., McDonald, W., Miller, R. (1988). Underpricing of new issues and the choice of auditors as a signal of investment banker reputation. Accounting Review, 63, 605-622.

Barry, C., Muscarella, C., Peavy, J., Vetsuypens, M. (1990). The role of venture capital in the creation of public companies: evidence from the going-public process. Journal of Financial Economics, 2 (27), 447-471.

Beaty, R., Welch, I. (1986). Investment bankin, reputation, and the underpricing of initial public offerings. Journal of Financial Economics, 15, 213-232.

Bodnaruk, A. (2009). Proximity always matters: local bias when the set of local companies changes. The European Financial Review, 13, 629-656.

Booth, J., Chua, L. (1996). Ownership dispersion, costly information, and the IPO underpricing. Journal of Financial Economics, 41, 291-310.

Booth, J., Smith, R. (1986). Capital raising, underwriting and the certification hypothesis. Journal of Financial Economics, 15, 261-281.

Brav, A., Gompers, P. (2003). The role of lockups in initial public offerings. The Review of Financial Studies, 1 (16), $1-29$.

Carter, R., Manaster, S. (1990). Initial Public Offerings and Underwriter Reputation. Journal of Finance, 45, 10451067.

Chachine, S. (2006). The impact of founders ownership, social impact and investors on IPO stockmarket performance. Academy of Management Journal.

Coval, J., Moskowitz, T. (2005). The role of IPO underwriting syndicates: Pricing, information production and underwriter competition. The Journal of Finance, 60, 443-486.

Grinblatt, M., Hwang, C. (1989). Signaling and the pricing of unseasoned new issues. Journal of Finance, 44, 393-420.

Gurun, U., Butler, A. (2012). Don't believe the hype: local media slant, local advertising, and firm value. Journal of Finance, 2 (67), 561-597.

Hughes, P., Thakor, A. (1992). Litigation risk, intermediation and the underpricing of initial public offerings. Review of Financial Studies, 5, 709-742.

Jewartowski, T., Lizinska, J. (2012). Short- and long-term performance of Polish IPOs. Emerging Markets Finance and Trade, 2 (48), 59-75.

Knopf, J., Teall, J. (1999). The IPO effect and measurement of risk. Journal of Accounting and Finance, 2 (4), $35-52$.

Lin, T., Smith R. (1998). Insider reputation and selling decisions: the unwinding of venture capital investment during equity IPOs. Journal of Corporate Finance, 3 (4), 241-263.

Loughran, T., Ritter, J. (2002). Why don't issuers get upst about leaving money on the table in IPOs? Review of Financial Studies, 65, 413-443.

Loughran, T., Ritter, J., Rydqvist, K. (published in 1994, updated May 4, 2016). Initial Public Offerings: International Insights. Pacific-Basin Finance Journal, 165-199.

Lyn, E., Zychowicz, E. (2003). The performance of new equity offerings in Hungary and Poland. Global Finance Journal, 14, 181-195.

Massa, M., Simonov, A. (2006). Hedging, familiarity and portfolio choice. Review of Financial Studies, 19, $633-685$.

Megginson, W., Weiss, K. (1991). Venture capitalist certification in initial public offerings. The Journal of Finance, 3 (46), 879-903.

Menyah, K., Paudyal, K., Inyangete, C. (1995). Subscriber return, underpricing, and long-term performance of UK privatization initial public offerings. Journal of Economics and Business, 5 (47), 473-495.

Michaely, R., Shaw, W. (1994). The pricing of initial public offerings: Tests of adverse selection and signaling theories. Review of Financial Studies, 7, 279-319.

Mohan, J., Chen, R. (2001). Information content of lock-up provisions in initial public offerings. International Review of Economics Finance, 1 (10), 41-59.

Muscarella, C., Vetsuypens, M. (1989). A simple test of Baron's model of IPO underpricing. Journal of Financial Economics, 24, 125-136. 
Paudyal, K., Saadouni, B., Briston, R. (1998). Privatization initial public offerings in Malaysia: initial premium and long-term performance. Pacific-Basin Finance Journal, 427-451.

Rhee, S. (2002). A review of the New Issue Puzzles. OECD Round table on Capital Markets Round Table on Capital Market Reform in Asia. Tokyo.

Ritter, J., Welch, I. (2002). A review of IPO activity, pricing, and allocations. Journal of Finance, 57, $1795-1828$.

Rock, K. (1986). Why new issues are underpriced. Journal of Financial Economics, 15, 187-212.

Sieradzki, R. (2013). Does it pay to invest in IPOs? Evidence from the Warsaw Stock Exchange. Warsaw: National Bank of Poland.

Sukacz, D. (2005). Pierwszy oferty publiczne na rynkach kapitalowych. Cedetu.

Tinic, S. (1988). Anatomy of initial public offerings of common stock. Journal of Finance, 43, 789-822.

Titman, S., Trueman , B. (1986). Information quality and the valuation of new issues. Journal of Accounting and Economics, 8, 159-172.

Welch, I. (1989). Seasoned offerings, imitations costs and the underpricing of initial public offerings. Journal of Finance, 44, 421-450.

Welch, I. (1992). Sequential sales, learning and cascades. Journal of Finance, 47, 695-732.

\section{DETERMINANTY UNDERPRICINGU PIERWSZYCH OFERT PUBLICZNYCH NA GPW}

Streszczenie: $\mathrm{Cel}$ - celem tego artykułu jest przedstawienie dowodów na temat początkowego zwrotu (IR) wstępnych ofert publicznych (IPO) na rynku akcji w Polsce oraz określenie czynników determinujących początkowy underpricing IPO na Giełdzie Papierów Wartościowych w Warszawie (GPW) w okresie od 2005 r. do 2015 r.

Metodologia badania - ocena empiryczna i szacowanie wyników regresji na podstawie informacji uzyskanych z baz danych takich jak: Bloomberg, Dealogic i MergerMarket.

Wynik - artykuł dostarcza dowodów na asymetrię informacji, teorie behawioralne, a także własnościowe i strukturalne. Wyniki wskazują sześć zmiennych, które mają wpływ na stopień underpricingu, a mianowicie zaangażowanie funduszy PE i VC w strukturę własności spółki przeprowadzającej IPO, nowe akcje emitowane jako procent całkowitych wpływów z publicznej oferty publicznej, niepewność ex-ante zmierzona według skrajnej wartości Parkinsona, cena IPO została ustalona na poziomie maksymalnym, obroty akcjami sprzedanymi w czasie debiutu oraz zwrot na giełdzie sześć miesięcy przed debiutem.

Oryginalność/wartość - niniejszy artykuł stanowi wkład do literatury dostarczającej nowych dowodów na stosunkowo mało przeszukiwane zjawisko underpricingu IPO i ich determinanty na polskim rynku akcji.

Słowa kluczowe: pierwsza oferta publiczna, underpricing; Giełda Papierów Wartościowych

\section{Citation}

Kavalenka, Y. (2018). Determinants of IPO Underpricing on the Warsaw Stock Exchange. Finanse, Rynki Finansowe, Ubezpieczenia, 1 (91), 257-267. DOI: 10.18276/frfu.2018.91-21. 